\title{
First record of mass wild waterfowl mortality due to Clostridium botulinum in Brazilian semiarid
}

\author{
PEDRO C. LIMA, IVERALDO S. DUTRA, FRANCISCO A.A. ARAÚJO, RICARDO \\ LUSTOSA, CAIO G. ZEPPELINI \& CARLOS R. FRANKE
}

\begin{abstract}
In 2008, 270 wild birds from aquatic environments were found dead or debilitated on the banks of smaller lakes that had been formed due to the decrease in the level of the holding lake of the Sobradinho Dam located on the São Francisco River in the Caatinga of Bahia, Brazil. The outbreak occurred months after the dam's partial drainage, with the formation of puddles that accumulated decomposing organic material. Amongst the 270 individuals examined and/or found dead, the majority (50\%) of the birds found belonged to the Anatidae family. The debilitated birds presented neurological clinical signs including lack of motor coordination, weakness, grave flaccid paralysis in the legs, wings, neck and eyelids, diarrhea, and dyspnea. Tissue samples of the birds were collected, as were water samples and samples of the substrate of the lakes. Zoonotic arboviroses or heavy metals were not detected. Analyses of liver and digestive tract content samples through bioassay and serum neutralization in mice revealed the presence of type $C$ botulinic toxin in the viscerae samples, and type $D$ in sediment samples. According to our knowledge, this is the first record of an outbreak of botulism in wild birds in natural conditions in Brazil.
\end{abstract}

Key words: botulinum toxins, Clostridium botulinum, wild birds, Caatinga, aquatic environment.

\section{INTRODUCTION}

Large scale mortality events in wild birds can be attributed to different causes, such as viral (Deliberto et al. 2009), bacterial infection (Wobeser 1997), as well as intoxication from heavy metals (Jones et al. 1983). Die-off events of considerable scale (i.e. when a large part or all of a local population dies) demand timely assessment and study due to the possibility of epizootic outbreak (Morner et al. 2002), which would pose a threat to human health due to the risk of spillover events (Zeppelini et al. 2016).

Botulism is a disease caused in animals and humans by ingestion of with one of the most potent neurotoxins found in nature, botulinum toxins, produced by the Gram-positive, anaerobic bacteria Clostridium botulinum (Austin 2001). On a world-wide basis, avian botulism is the most significant disease of waterbirds and has potential to cause significant population declines in some species (Rocke 2006). Eight types of botulinic toxins, currently classified from $\mathrm{A}$ to $\mathrm{H}$, with each bacterial strain producing one or two toxins in different levels (Barash \& Arnon 2014): the types A, B, E and F are associated with human cases, while C, D, E and both $C / D$ and $D / C$ neurotoxin mosaics are found in animal botulism (Nakamura et al. 2010, Chipault et al. 2015). The spores of C. botulinum can be found in terrestrial or aquatic (fresh and salt water) environments throughout the world (Austin 2001). In aquatic environments, there are several reports of outbreaks of botulism in fish 
farms (Cann \& Taylor 1982, Huss \& Eskilden 1974), with the largest outbreaks occurring during the summer, due to high temperatures (Yule et al. 2006). High temperature of water during avian botulism outbreaks in Spain (Vidal et al. 2013) and South Korea (Son et al. 2018) have also been reported. Type $\mathrm{C}$ botulism is considered the main cause of botulism in birds (Wobeser 1997), has been diagnosed in wild waterbirds in at least 28 countries and on every continente except in Antarctica (Rocke 2006) and mortality can occur in sporadic outbreaks in birds that feed in water environments, parting from the mobilization of pathogenic spores incubated in the sediments (Espelund \& Klaveness 2014). The collection of deceased animals can reduce the risk of further mortality and contamination (Evelsizer et al. 2010). Type $E$ is more geographically restricted compared to type $\mathrm{C}$, causing high mortality of waterbirds in the Great Lakes region of the USA (Chipault et al. 2015).

The lack of specific legislation about the appropriate final destination of cadavers in animal husbandry in Brazil is considered one of the main causes of environmental contamination by C. botulinum (Dutra et al. 2005, Dutra \& Döbereiner 1995), and additionally possibly the source of wildlife infection in mass mortality events. The absence of information about proper sanitation procedures from the official government and little knowledge on the part of producers about the sanitary and economic consequences of leaving decomposing cadavers in the field favor environmental contamination and intoxication events (Curci et al. 2007). It is important to stress, however, that natural aquatic environments often harbor the ideal conditions for outbreaks (Espelund \& Klaveness 2014), as well as areas of extensive cattle herding that cross migratory bird routes.

In Brazil few studies reported outbreaks of botulism in wild birds and when happened, there described in the South of the country in zoo conditions (Schonhofen \& Ferreira 1981, Cubas 1996, Raymundo et al. 2012) or in establishment with domestic or wild captivity birds (Oliveira Junior et al. 2016). However, in wild birds under natural conditions, to our knowledge, there is no report in Brazil. Botulism as a differential diagnosis to arboviruses is a relevant condition for sanitary surveillance, which may have wild birds as reservoirs. The current study investigates an event of mass mortality and morbidity of wild birds on an aquatic environment registered in the state of Bahia, Brazil, which has been attributed to a Botulism outbreak.

\section{MATERIALS AND METHODS}

The study was performed in the area surrounding the holding lake of the Sobradinho Dam, located on the São Francisco River in the municipality of Remanso, Bahia, Brazil. The municipality of Remanso has an area of 4,694 $\mathrm{km}^{2}$, and a population of 38,957 inhabitants (IBGE 2016). The region is part of the Caatinga biome, and its economy is based on commerce and farming (cutivation and livestock).

Throughout 2008, the lake retained only $19.0 \%$ of its holding capacity due to an extended drought. This led to the formation of small, shallow and isolated lakes, with a large amount of decomposing organic material and low free oxygen content, where the dead and debilitated birds were found. Five of these small lakes (EPI 1 to 5) were included in the study (Figure 1). The inquest about the mortality and morbidity of the birds was performed by the Ministry of Health, as part of the actions of the federal program on epidemiological vigilance, with the participation of specialized technicians, and had a primary goal of investigating possible risk for human populations, other wild life, and the environment, as well as the possible involvement of emerging viruses such as Avian Influenza and West Nile Fever having infected the birds. 
The general survey for the ave-fauna in the study area, including those found dead or debilitated, was performed during January and February of 2008, through observation with the naked eye or using Swarovski 8 X 30 binoculars. Morphological, behavioral and vocalization characteristics were considered for the identification of species. The birdsongs were recorded with a Sennheiser ME-66 directional microphone and a digital recorder MP3 Edirol. The technique of audio recognition was used, reproducing a recording of the audio of the birdsong or the calling of a particular species to stimulate the approaching of the respective bird or a vocal response (Motta-Junior et al. 2010). The taxonomy and nomenclature of the registered species followed the norms of the Brazilian Committee for Ornithological Registers (Comitê Brasileiro de Registros Ornitológicos/ CBRO 2014), and for the subspecies level, the taxonomy proposed in the "Guia Completo para Identificação das Aves do Brasil" by Granstau (Grantsau 2010) was used. Characteristics such as endemism and feeding habits followed the classifications presented by Sick (Sick 1997).

A total of 270 birds were recorded, comprising both the dead $(N=225)$ and debilitated $(N=45)$. Biological samples of 45 debilitated birds were collected: blood $(\mathrm{N}=40)$, cloacae swabs ( $\mathrm{N}=27)$, and viscera (brain, lung, liver and kidneys) $(\mathrm{N}=43)$. The previous samples were stored in liquid nitrogen. Aliquots of the

\section{Legend \\ I.-- Epizootic Concentration Locales for the collection of birds}

Brazil

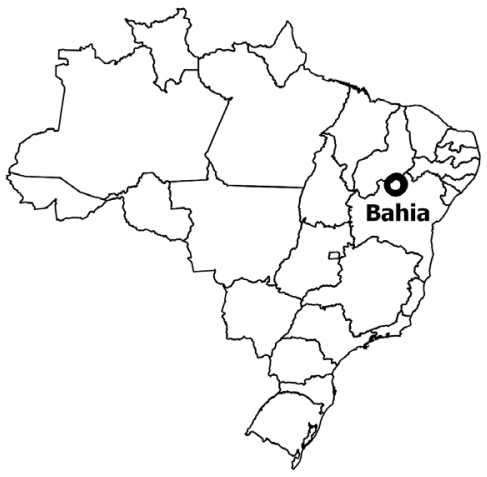

System of coordinates: Lat/Long

Datum: Sirgas 2000

Source: Image from ERIS data and IBGE (2010)
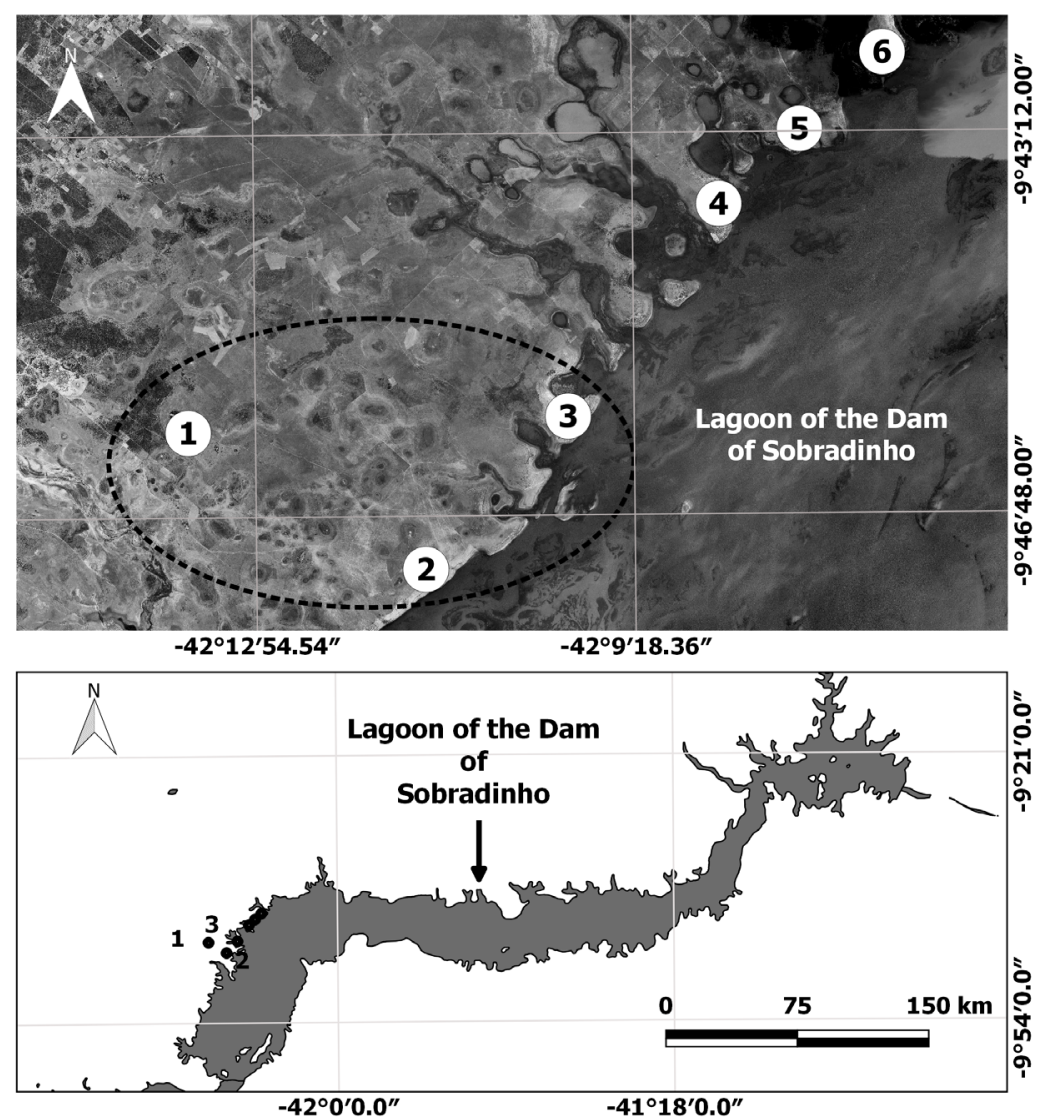

Figure 1. Map of the study area. The black polygon marks the area of concentration of the epizootic episode. In the left, the position of the area within the country and the Caatinga Biome; in the right, a detailed view of the sampling area. 
biological samples were sent to the Evandro Chagas Institute, for isolation research of the 19 different arboviruses and/or their serology. The presence of avian influenza was also investigated by LANAGRO (National Agricultural Laboratory/Ministry of Agriculture) given the high number of birds which were found dead or debilitated belonging to the Anseriformes order (ducks, geese, swans), which are sensitive to the influenza virus (Deliberto et al. 2009). Cell cultures were used for viral isolation (cells C6/36clone Aedes albopictus and VERO - kidney of a green monkey), in which the samples collected from the birds were inoculated, and examined daily to visualize the cytopathogenic effect. The presence of viral infection was confirmed by indirect antibody fluorescent test (IFI) (Gubler et al. 1984), using polyclonal antibodies from the main antigenic groups of the parvoviruses that occurs in Brazil, including representatives from the five principal families (and principal genera) of the arboviruses: (Togaviridae, Alphavirus, Group A); (Flaviviridae, Flavivirus group B); (Bunyaviridae, Orthobunyavirus; group C), (Bunyaviridae, Phlebovirus; Phlebotomus); (Reoviridae, Orbivirus; Changuinola); (Rhabdoviridae, Vesiculovirus; VSV).

In order to evaluate the possible involvement of water contamination in this bird mortality event from mining, agricultural or urban sewage contamination in the areas surrounding the lake, water samples, substrates, algae and snails were collected and sent for bacteriological and physicochemical analysis at CETREL Laboratory (Environmental Protection Company for the Petrochemical Pole in Camaçari, Bahia). To test for heavy metals, 4.5 liters of water from each of the studied lakes were collected (EPI 1 -5). The water samples were stored in $1.5 \mathrm{~L}$ amber flasks, identified, and refrigerated. The samples were analyzed in an atomic absorption spectrometer using the SMEWW 3120 B method (for boron, barium, beryllium, calcium, cadmium, cobalt, chrome, copper, iron, potassium, lithium, magnesium, molybdenum, manganese, sodium, nickel, lead, silicon, tin, strontium, thallium, vanadium, zinc, arsenic, mercury, antimony and selenium).

Sediment (silt), algae, and snail samples were collected from the five lakes and stored in plastic bags, identified, and conserved in ice. The material was sent to the CETREL Laboratory within 24 hours. For microbiological and physicochemical exams, 500 milliliters of water from three of the five sampled lakes were selected at random. The levels and measurements of the following were analyzed: free cyanide, conductivity, DQO-RF, the phenols index, pH, surfactants, CR. IONIC, chloride, fluoride, $\mathrm{N}$-nitrate, $\mathrm{N}$-nitrite, and sulfate.

Given the clinical symptoms observed in the debilitated birds suggested botulism, samples from different duck species (of the family Anatidae), in which mortality was more expressed, as well as samples from sediment (silt), algae, and snails, were collected from the five lakes, conserved at $-20^{\circ} \mathrm{C}$, and analyzed at the Laboratory of Infectious Diseases of Animals, at the College of Veterinary Medicine and the State University of São Paulo (UNESP). These samples (liver, gizzard and hindgut contents) were processed and analyzed for botulinum toxin through the standard bioassay technique in mice as recommended by the centers for Disease Control and Prevention - CDC/USA and described by Dutra (2001), using monovalent antitoxins (types $C$ and $D$, provided by the Ministry of Agriculture, Livestock and Supply). The presence of $C$. botulinum in sediment, algae and snail samples from the puddles were evaluated using the filtered portion of the supernatant of the anaerobic bacterial culture in Wright's medium inoculated with $1 \mathrm{~g}$ of each material; following five days of incubation at $37{ }^{\circ} \mathrm{C}$ (Souza et al. 2006). The presence of the toxin in the supernatant followed the technique described for the avian samples. 


\section{RESULTS}

The general ave-fauna registered at the study area comprised of 64 species from 24 families, of which 17 species (26.6\%) are considered migratory, 43 (67.2\%) residents, and 4 (6.3\%) with resident and/or migratory characteristics depending on changes in the humid environment (Table I). Two hundred and seventy wild birds, either debilitated ( $N=225)$ or dead ( $N=45$ ), were found belonging to 16 species, of which $68.8 \%$ (11/16) were migratory, $3.1 \%(2 / 16)$ were resident and two species, Aramus guarauna and Podiymbus podiceps (3.1\% 2/16) which could be resident or migratory depending on the environmental conditions.
Regarding feeding guild division, species that feed on small invertebrates and filterfeeders such as Anatidae, Charadriidae and Recurvirostridae were the most affected, followed by vertebrate predators (e.g. Ardeidae: $10.3 \%, 28 / 270)$. Those of the family Anatidae were the most affected with debilitated or dead individuals registered of all the eight species identified in the ave-fauna survey in the area studied (Table I). Of the nine species of Ardeidae identified, the snowy egret (Egretta thula) represented almost all dead or debilitated individuals $(\mathrm{N}=27,10 \%)$. Of the two species of Charadriidae identified, only the southern

Table I. Families and species of birds identified in the study area, discriminated by number of individuals debilitated and dead, feeding habits and foraging locale in relation to the water depth of the small lakes near to the Holding Lake of the Sobradinho Dam; in the municipality of Remanso, Bahia in 2008.

\begin{tabular}{|c|c|c|c|}
\hline Family/Species & Debilitaded and dead & Diet & Foraging locale \\
\hline \multicolumn{4}{|c|}{ Podicipedidae } \\
\hline Podilymbus podiceps & 1 & Fish and insects & $L R^{*}$ \\
\hline \multicolumn{4}{|c|}{ Phalacrocoracidae } \\
\hline Phalacrocorax brasilianus & 2 & Fish & $"$ \\
\hline \multicolumn{4}{|c|}{ Ardeidae } \\
\hline Egretta thula & 27 & Fish and amphibians & “ \\
\hline Bubulcus ibis & 0 & “ & “ \\
\hline Nycticorax nycticorax & 1 & “ & “ \\
\hline Butoridis striatus & 0 & “ & “ \\
\hline Ardea cocoi & 0 & “ & $L F^{* *}$ \\
\hline Ardea alba & 0 & “ & “ \\
\hline Tigrisoma lineatum & 0 & “ & “ \\
\hline Mycteria americana & 0 & “ & “ \\
\hline Jabiru mycteria & 0 & “ & “ \\
\hline \multicolumn{4}{|c|}{ Anatidae } \\
\hline Dendrosygna autumnalis & 96 & Filter feeders & $L R$ \\
\hline Dendrosygna viduata & 68 & $“$ & “ \\
\hline Amazonetta brasiliensis & 35 & “ & “ \\
\hline Dendrosygna bicolor & 4 & “ & “ \\
\hline Cairina moschata & 3 & “ & “ \\
\hline
\end{tabular}


Table I (continuation)

\begin{tabular}{|c|c|c|c|}
\hline Family/Species & Debilitaded and dead & Diet & Foraging locale \\
\hline Netta erythrophthalma & 3 & “ & “ \\
\hline Anas bahamensis & 2 & “ & “ \\
\hline Sarkidiornis melanotos & 2 & “ & “ \\
\hline \multicolumn{4}{|l|}{ Aramidae } \\
\hline Aramus guarauna & 2 & Aquatic mollusc & $L R$ \\
\hline \multicolumn{4}{|l|}{ Rallidae } \\
\hline Gallinula chloropus & 0 & Omniverous & $\mathrm{S}^{* * *}$ \\
\hline Porphyrio flavirostris & 0 & “ & “ \\
\hline Jacanidae & & “ & \\
\hline Jacana jacana & 2 & Insects and amphibians & $L R$ \\
\hline \multicolumn{4}{|l|}{ Recurvirostridae } \\
\hline Himantopus mexicanus & 6 & Insects/larvae & “ \\
\hline Charadriidae & & & “ \\
\hline Vanellus chilensis & 16 & “ & “ \\
\hline Charadrius collaris & 0 & “ & “ \\
\hline \multicolumn{4}{|l|}{ Sternidae } \\
\hline Phaetusa simplex & 0 & Fish & $\mathrm{S}$ \\
\hline \multicolumn{4}{|l|}{ Cathartidae } \\
\hline Coragyps atratus & 0 & Scavenger & $M^{* \star \star \star}$ \\
\hline Cathartes aura & 0 & “ & “ \\
\hline Cathartes burrovianus & 0 & “ & “ \\
\hline \multicolumn{4}{|l|}{ Accipitridae } \\
\hline Rupornis magnirostris & 0 & Predacious & M \\
\hline Rostrhamus sociabilis & 0 & Aquatic mollusc & S \\
\hline \multicolumn{4}{|l|}{ Falconidae } \\
\hline Caracara plancus & 0 & Predacious & M \\
\hline Mivalgo chimachima & 0 & “ & “ \\
\hline Falco femoralis & 0 & “ & “ \\
\hline Falco sparverius & 0 & “ & “ \\
\hline Falco peregrinus & 0 & $“$ & “ \\
\hline Columbidae & 0 & Seeds & \\
\hline Columbina minuta & 0 & “ & M \\
\hline Columbina picui & 0 & “ & “ \\
\hline Columbina squammata & 0 & “ & “ \\
\hline Columbina talpacoti & 0 & “ & “ \\
\hline Leptotila verreauxi & 0 & “ & “ \\
\hline
\end{tabular}


Table I (continuation)

\begin{tabular}{|c|c|c|c|}
\hline Family/Species & Debilitaded and dead & Diet & Foraging locale \\
\hline Patagioenas picazuro & 0 & “ & “ \\
\hline Zenaida auriculata & 0 & “ & “ \\
\hline Cuculidae & & & “ \\
\hline Crotophaga ani & 0 & Omniverous & $“$ \\
\hline Guira guira & 0 & $“$ & $“$ \\
\hline Nyctibiida & & & “ \\
\hline Chordeiles pusilus & 0 & Insects & $“$ \\
\hline \multicolumn{4}{|l|}{ Picidae } \\
\hline Ceryle torquatus & 0 & Fish & S \\
\hline \multicolumn{4}{|l|}{ Furnariidae } \\
\hline Certhiaxys cinnamomeus & 0 & Insects and larvae & S \\
\hline Furnarius rufus & 0 & $“$ & $S / M$ \\
\hline Furnarius figulus & 0 & $“$ & S \\
\hline Tyrannidae & & Insects & $“$ \\
\hline Fluvicola albiventer & 0 & $“$ & $“$ \\
\hline Fluvicola nengeta & 0 & $"$ & $“$ \\
\hline Pitangus sulphuratus & 0 & Omniverous & $“$ \\
\hline Tyrannus melancholicus & 0 & $“$ & $“$ \\
\hline Tyrannus savanna & 0 & $“$ & M \\
\hline \multicolumn{4}{|l|}{ Hirundinidae } \\
\hline Progne tapera & 0 & $“$ & $S / M$ \\
\hline Progne subis & 0 & $“$ & $“$ \\
\hline Hirundo rustica & 0 & $“$ & “ \\
\hline Tachycineta albiventer & 0 & $“$ & $“$ \\
\hline \multicolumn{4}{|l|}{ Mimidae } \\
\hline Mimus saturninus & 0 & Omniverous & M \\
\hline \multicolumn{4}{|c|}{ Cardinalidae } \\
\hline Paroaria domicana & 0 & Seeds & $"$ \\
\hline \multicolumn{4}{|c|}{ Passeridae } \\
\hline Passer domesticus & 0 & Omniverous & $“$ \\
\hline \multicolumn{4}{|c|}{ Icteridae } \\
\hline Sturnella superciliaris & 0 & Omniverous & $S / M$ \\
\hline Families $=24$. Species $=64$ & $N=270$ of 16 species & & \\
\hline
\end{tabular}

Key: ${ }^{*} \mathrm{LR}=$ the depth of shallow water, ${ }^{* *} \mathrm{LF}=$ depth of deep water, ${ }^{* * *} \mathrm{~S}=$ on the water surface and ${ }^{* * *} \mathrm{M}=$ on the banks. 
Table II. Result of direct research of botulinum toxin through the bioassay test, following the Centers for Disease Control and Prevention, USA, assay, and neutralization in mice of the biological material from the different species of ducks found dead.

\begin{tabular}{|c|c|c||c|c|}
\hline Species of Ducks & Toxin & Gizzard & Intestinal content & Liver \\
\hline Amazoneta brasiliensis & Type C & - & + & + \\
\hline Amazoneta brasiliensis & Type C & + & + & + \\
\hline Dendrocygna autumnalis & Type C & - & - & + \\
\hline Denseicygna autumnalis & & - & - & - \\
\hline Dendrocygna autumnalis & & - & - & - \\
\hline Dendrocygna viduata & & - & - & - \\
\hline Dendrocygna viduata & & - & - & - \\
\hline Dendrocygna viduata & & - & - & - \\
\hline
\end{tabular}

*The samples marked in red contained botulinum toxin to provoke symptoms in mice but without causing death. By the technique, they are considered negative types even having been neutralized by the anti-toxin $\mathrm{C}$.

lapwing (Vanellus chilensis) appeared among the debilitated or dead individuals.

The 45 birds of the 11 species found debilitated presented good nutritional states; however, there were signs of apathy, inability to move or fly, dry ocular conjunctivitis, paralysis of the nictate membrane and ocular swelling, open wings, fallen necks, and died within a short period of time. The biological samples tested by the Evandro Chagas Institute, were negative to the presence of the West Nile or other arboviruses, as well as for H5N1, and any other virulent strains of the avian influenza.

The heavy metal analysis did not detect any parameters above the limits recommended by CONAM (National Environment Council Ministry of the Environment). These results, despite referring to the admissible toxicity levels for humans, indicate no causal role in the death of the birds. Moreover, aside from the birds, no other animal species associated with the small lakes studied were found dead. The microbiological and physicochemical exams showed that the lakes were eutrophicated.
The $\mathrm{C}$ type botulinum toxin was identified in 3 of the 8 biological samples from the different duck species observed dead, which is normally involved in botulism in birds (Table II). In the 3 sediment samples from the lakes, presence of $C$. botulinum were detected, as well as the $C(1)$ and $D(1)$ toxins, the latter normally involved in cattle outbreaks (Woudstra et al. 2012). Furthermore, one sample was not neutralized by type C or D monovalent antitoxins, remaining unclassified. The samples of molluscs and algae collected in the study area were negative for the presence of both the bacteria and botulinum toxins.

\section{DISCUSSION}

The results indicate a local $C$. botulinum outbreak causing mass mortality and morbidity amongst the wild bird fauna. The decomposition of organic matter in natural or artificial aquatic environments (such as the case in the Sobradinho Dam, which was drained and formed small puddles) can create favorable conditions for the reproduction and proliferation of $C$. botulinum. In fact, the detection of the type $\mathrm{C}$ botulinic 
toxin in the bioassays prove the cause of the mortality event as observed and delimitated by clinical and epidemiological observations. The presence of type D toxin C. botulinum spores in the sediment does not affect the diagnosis, as the co-detection is common in natural environments (Souza et al. 2006). The analysis discards the possibility of a mass death event due to heavy metal poisoning, the neurological manifestations and symptoms of which could be mistakenly attributed to botulism (e.g. weakness, walking in circles, rhythmic balancing of the head, convulsions, ataxia, and paralysis) (Jones et al. 1983). Despite the presence of mining companies in the region of the São Francisco River, the levels of heavy metals found in the samples were within admissible parameters. However, it is not possible to completely discard or associate the possibility of interactions between these substances and other causal agents in the increase of the susceptibility and weakening of the animals. It is also important to stress that tests were performed only for type $C$ and $D$ toxins, meaning that the negative results of the algae and mollusk samples could be due to the specificity of the monovalent antitoxins.

The mice bioassays detecting the type $\mathrm{C}$ toxin in the birds' viscerae gives solid proof for the suggested diagnosis of the outbreak. Together with the clinical observations and epidemiologic data, they support the diagnosis of mass mortality by botulism in this report. Although type D C. botulinum spores in the sediment samples were found, it does not conflict with the diagnosis of a type C outbreak, as it is a plausible finding in natural/seminatural environments and also shared by several animal species (Souza et al. 2006). In the present study only the techniques for detection of toxins in the viscerae, stomach and intestinal content of the birds, sediment cultivation, and bioassays for the $C$ and $D$ toxins, making it impossible to evaluate the presence of C, D,D/C mosaic toxins by PCR as performed by Nakamura et al. (2010), or to other types of $C$. botulinum. In this context, we cannot exclude the possibility of existence of environmental contamination by other strains; as well as the non-detection of $C$. botulinum in the algae and mollusk samples is plausible, as few samples were used for this assay.

The analyses performed at the Evandro Chagas Institute did not identify the presence of antibodies or arboviruses, and nor did the LANAGRO detect the presence of pathogen strains of the avian influenza virus. The occurrence of mortality in birds is always a warning of potential risks to human health and for the poultry production of a region, and the corresponding possible involvement of emerging viruses is a priority in investigations, since birds are the third most frequent source of parvovirus isolation, following humans and rodents (Araujo et al. 2012).

A differential diagnostic is important where outbreaks occur in bird populations accompanied by high mortality, considering that this can be related to several causes including West Nile Virus and other arboviruses (which can infect birds, horses and humans), avian influenza, avian botulism (Manarolla et al. 2009, Spackman et al. 2002, Włodarczyk et al. 2014), as well as the presence of more species from the genus Flavivirus (Scaramozzino et al. 2001) which also causes phenomena of mortality. Despite the greatest mortality of birds having occurred during the period of the current study in 2008, other episodes of bird death have occurred in the region in 2012, 2013 and 2015. In Brazil, there are no programs focused on environmental sanitation such as carcass collection in mass mortality events such as the one investigated here. According to Evelsizer et al. (2010), such measures are important to mitigate the 
risk of new outbreaks, mass mortality and environmental contamination.

In the study area, the presence of large flocks of vultures (family Cathartidae) was observed, from the following species: black vulture (Coragyps atratus), turkey vulture (Cathartes aura) and the lesser yellow-headed vulture (Cathartes burrovianus) which feed on dead bird carcasses. The members of this family are scavenger and, resistant to botulism, cholera and anthrax. Possible explanations for the resistance of vultures to pathogens were previously described (Carvalho et al. 2003). In the current study, no members of this avian family were found debilitated or dead, which corroborates the observations in literature (Cann \& Taylor 1982, Hauschild \& Dodds 1993, Huss \& Eskilden 1974). Two species of raptors were observed, the yellow-headed caracara (Milvalgo chimachima) and the southern caracara (Caracara plancus), which feed on fresh bird carcasses. Despite this, none of these species were found dead or debilitated.

There were no reports on deaths of other animals in the region, even though production animals (horses, cattle and sheep) regularly consume water from the lakes where there were debilitated and dead birds; this is possibly due to the standardized practice of vaccinating domestic animals against botulism in the region, due to its endemicity. The ingestion of water contaminated with botulinum toxin could cause water-borne botulism in production animals (Dutra et al. 2001, Souza et al. 2006). The link between contaminated water ingestion and botulism outbreaks has been observed in prior literature (Dutra et al. 1990). Water-borne botulinum intoxication have affected cattle in Senegal and South Africa (Doutre 1969, Kriek \& Odendaal 2004, Thiongane et al. 1984), and buffalo in Brazil (Langenegger \& Döbereiner 1988).
Although C. botulinum is naturally found in soil and sediment, which create the baseline possibility of outbreaks, it is important to take in consideration human uses in the area such as livestock rearing, that can contribute to the environmental contamination. Independent of vaccination against type $C$ and $D$ toxoids, bovines are known for carrying $C$. botulinum spores and shedding them with their feces, with the risk of contaminating water reservoirs (Souza et al. 2006). Under such circumstances, considering that there is no policy on removing bovine carcasses (which represent a source of contamination) from grasing sites, and the management of the water reservoirs such as the Sobradinho Dam, an environmental and sanitary surveillance practice makes itself fundamental to prevent and/or mitigate such events (Evelsizer et al. 2010, Espelund \& Klaveness 2014).

The samples of molluscs and algae collected in the study area were negative for spores and botulinum toxin. The sediment samples from the small lakes revealed the presence of spores of C. botulinum, and types $C$ and $D$ of botulinum toxin, as well as an unidentified botulinum toxin. Tests on the samples taken from the three species of ducks revealed the presence of type $\mathrm{C}$ botulinum toxin in gizzard samples, stomach content, and the liver (Table II); this toxin is generally associated to avian botulism (Yule et al. 2006), while type D are associated with the contamination and mortality of cattle.

The shallowness of the bodies of water, consequent decrease in dissolved oxygen, increase in temperature, and presence of decomposing sediments are favorable for the growth of C. botulinum, which benefits from these conditions in its multiplication and liberation of its toxins (Espelund \& Klaveness 2014). Invertebrate fauna seems to play an important role in the availability of the toxin for wild ducks, forming a bioaccumulation chain 
following a environment, invertebrate fauna and duck predator route (Rocke \& Bollinger 2007). This could serve as a potential explanation as to why birds of the Anatidae family were most affected in the current outbreak.

The results presented in this study reveal the first case of avian botulism in wild birds in an aquatic environment in Brazil in natural conditions. Despite the fact that this disease is well studied in commercial animals, its impact on wild animals is not yet known in the country and should be researched, both for the conservation of wild animals, as well as for the update of the sanitary guidelines governing the discard of carcasses by the agrobusiness, which would contribute to the reduction of environmental contamination of Clostridium botulinum.

\section{Acknowledgments}

We thank the Fundação de Amparo à Pesquisa do Estado da Bahia (FAPESB); the professionals of the Municipal Health Secretariat in Remanso and the veterinarians and technicians of ADAB who helped in the field research. We additionally thank the National Center for Conservation Research of Wild Birds/CEMAVE and the Instituto Evandro Chagas (IEC) for their support. We also thank those at the Secretariat for Health Vigilance/Ministry of Health, especially our colleagues Alessandro Pecego Romano, Pedro Henrique de Oliveira Passos, and Daniel Garkauskas. We would also like to acknowledge and thank our colleagues of the Health Secretariat in Bahia - SES/BA,DIVEP, DIRES/JUAZEIRO, the Agência de Defesa Agropecuária da Bahia (ADAB) (OFFICES IN JUAZEIRO AND REMANSO), the Centro de Recursos Ambientais da Bahia - CRA JUAZEIRO OFFICE, the Secretaria Municipal de Saúde (SMS) of the municipality of Remanso, Sanitary Vigilance, Epidemiological Vigilance, CETREL - the Environmental Monitoring Company for the Petrochemical Pole Camaçari/BA, and the Universidade Federal da Bahia(UFBA). To colleagues who contributed in fieldwork: Aramis Cardoso Beltrami - CGVAM/SVS/MS, Charles E.A. Oliveira - ADAB/JUAZEIRO, Edmar de Souza Freire - ADAB/REMANSO, Erivelton Souza Almeida- DAB/ REMANSO, Bruno R.P.D. Silva - CRA/JUAZEIRO, Erilson Rodrigues Azevedo - DIVISA/SMS/REMANSO, Marcos Jesuino L. Nogueira - CCZ/CAMACARI, Edgar Pinho Cerqueira - DIVEP/SES/BA, thank you for your time and contributions. CGZ would like to acknowledge FAPESB for hist doctorate fellowship. Additional thanks to the members of the Remanso Fishing Colony.

\section{REFERENCES}

ARAUJO FAA, LIMA PC, ANDRADE MA, JAYME VDS, RAMOS DG \& SILVEIRA SL. 2012. Soroprevalência de anticorpos "antiarbovírus" de importância em saúde pública em aves selvagens, Brasil - 2007 e 2008. Ciência Anim Bras 13: 115-123.

AUSTIN JW. 2001. Clostridium botulinum. In Food microbiology: Fundamentals and frontiers, 2nd ed., J Wildl Dis. Press, ASM, Washington.

BARASH JR \& ARNON S. 2014. A Novel Strain of Clostridium botulinum That Produces Type B and Type H Botulinum Toxins. J Infect Dis 209: 183-191.

CANN DC \& TAYLOR LY. 1982. An outbreak of botulism in rainbow trout, Salmo gairdneri Richardson, farmed in Britain. J Fish Dis 5: 393-399.

CARVALHO LR, FARIAS LM, NICOLI JR, SILVA MCF, CORSINO ATSM, LIMA LA, REDONDO RAF, FERREIRA PCP \& PINTO MEBM. 2003. Dominant culturable bacterial microbiota in the digestive tract of the American black vulture (Coragyps atratus Bechstein 1793) and search for antagonistic substances. Brazilian J Microbiol 34: 218-224.

CBRO - COMITÊ BRASILEIRO DE REGISTROS ORNITOLÓGICOS. 2014. Listas das aves do Brasil, $11^{\circ}$ ed., Comitê Brasileiro de Registros Ornitológicos, Brasília.

CHIPAULT JG, WHITE CL, BLEHERT DS, JENNINGS SK \& STROM SM. 2015. Avian botulism type $E$ in waterbirds of Lake Michigan, 2010-2013. J Great Lakes Res 41: 659-664.

CUBAS ZS. 1996. Special challenges of maintaining wild animals in captivity in South America. Rev Sci Tech Off int Epiz 15(1): 267-287.

CURCI VCLM, DUTRA IS, DÖBEREINER J \& JUNIOR JL. 2007. Précompostagem de cadáveres de bovinos acometidos pelo botulismo. Pesq Vet Bras 27: 157-161.

DELIBERTO TJ, SWAFFORD SR, NOLTE DL, PEDERSEN K, LUTMAN MW, SCHMIT BB, BAROCH JA, KOHLER DJ \& FRANKLIN A. 2009. Surveillance for highly pathogenic avian influenza in wild birds in the USA. Integr Zool 4: 426-439.

DOUTRE M. 1969. Fréquence au Sénégal du botulism animal d'origine hydrique. v. Élèv Med Vet Pays Trop 1: 29-31.

DUTRA IS. 2001. Epidemiologia, quadro clínico e diagnóstico pela soroneutralização em camundongo do 
botulismo em bovinos no Brasil, 1989-2000. Tese (LivreDocência), Universidade Estadual Paulista, Faculdade de Odontologia e Curso de Medicina Veterinária, Araçatuba, SP, $120 \mathrm{p}$.

DUTRA IS \& DÖBEREINER J. 1995. Eficácia da Vaxall - vacina botulínica bivalente - na prevenção do botulismo em bovinos. Hora Veterinária 93: 22-26.

DUTRA IS, DÖBEREINER J, ROSA IV \& BOND V. 1990. Botulismo de origem hídrica em bovinos no Brasil. In: 16th World Buiatrics Congress. Salvador-BA, p. 547-550.

DUTRA IS, DÖBEREINER J, ROSA IV, SOUZA LAA \& NONATO M. 2001. Surtos de botulismo em bovinos no Brasil associados à ingestão de água contaminada. Pesq Vet Bras 21: 43-48.

DUTRA IS, DÖBEREINER J \& SOUZA AM. 2005. Botulismo em bovinos de corte e leite alimentados com cama de frango. Pesq Vet Bras 25: 115-119.

ESPELUND M \& KLAVENESS D. 2014. Botulism outbreaks in natural environments - an update. Front Microbiol 5: 1-7.

EVELSIZER DD, CLARK RG \& BOLLINGER TK. 2010. Relationships between local carcass density in molting mallards during avian botulism outbreaks. J Wildl Dis 46(2): 507-513.

GRANTSAU R. 2010. Guia completo para identificação das aves do Brasil, 1a ed., Vento Verde, São Paulo.

GUBLER DJ, KUNO G, SATHER GE, VELEZ M \& OLIVER A. 1984. Mosquito Cell Cultures and Specific Monoclonal Antibodies in Surveillance for Dengue Viruses. Am J Trop Med Hyg 33: 158-165.

HAUSCHILD AHW \& DODDS KL. 1993. Clostridium botulinum ecology and control in foods. Marcel Dekker Inc, New York, NY.

HUSS HH \& ESKILDEN U. 1974. Botulism in farmed trout caused by Clostridium botulinum type E. Nord Vet Med 26: $733-738$.

IBGE - INSTITUTO BRASILEIRO DE GEOGRAFIA E ESTATÍSTICA. 2016. Infográficos: dados gerais do município da Remanso, Bahia.

JONES LM, BOOTH NH \& MCDONALD L. 1983. Farmacologia e Terapêutica em Veterinaria, 4a ed., Guanabara Koogan, Rio de Janeiro.

KRIEK NPJ \& ODENDAAL MW. 2004. Botulism 3: 1885-1902. In: Coetzer JAW, Thomson GR and Tustin RC. In: Infectious Diseases of Livestock. Oxford University Press, Cape Town.

LANGENEGGER J \& DÖBEREINER J. 1988. Botulismo enzoótico em búfalos no Maranhão. Pesq Vet Bras 8(1/2): 37-42.
MANAROLLA G, BAKONYI T, GALLAZZI D, CROSTA L, WEISSENBO CKH, DORRESTEIN G \& NOWOTNY N. 2009. Usutu virus in wild birds in northern Italy. Vet Microbiol 141: 159-163.

MORNER T, OBENDORF DL, ARTOIS M \& WOODFORD MH. 2002. Surveillance and monitoring of wildlife diseases. Rev Sci Tech l'OIE 21: 67-76.

MOTTA-JUNIOR JC, GRANZINOLLI MAM \& MONTEIRO AR. 2010. Miscellaneous ecological notes on Brazilian birds of prey and owls. Biota Neotrop 10: 355-360.

NAKAMURA K, KOHDA T, UMEDA K, YAMAMOTO H, MUKAMOTO M \& KOZAKI H. 2010. Characterization of the $D / C$ mosaic neurotoxin produced by Clostridium botulinum associated with bovine botulism in Japan. Vet Microbiol 140: 147-154.

OLIVEIRA JUNIOR CA, SILVA ROS, OLINDA RG \& LOBATO FCF. 2016. Botulism in non-ruminants in Brazil. Cienc Rural [online] 46(12): 2158-2165.

RAYMUNDO DL, HOHENDORF RV, BOABAID FM, BOTH MC, SONNE L, ASSIS RA, CALDAS RP \& DRIEMEIER D. 2012. Outbreak of type c botulism in captive wild birds. J Zoo Wildl Med 43(2): 388-390.

ROCKE TE. 2006. The global importance of avian botulism. In: Boere GC, Galbraith CA and Stroud DA (Eds). Waterbirds around the world. Edinburgh: The Stationery Office, $p$. 422-426.

ROCKE TE \& BOLLINGER TK. 2007. Avian botulism. Infect Dis wild birds, p. 377-416.

SCARAMOZZINO N, CRANCE J, JOUAN A, DEBRIEL D, STOLL F \& GARIN D. 2001. Comparison of Flavivirus universal primer pairs and development of a rapid, highly sensitive heminested reverse transcription-PCR assay for detection of flaviviruses targeted to a conserved region of the NS5 gene sequences. J Clin Microbiol 39: 1922-1927. SCHONHOFEN CA \& FERREIRA RG. 1981. First outbreaks of botulism in wild ducks in Curitiba. Braz Arch Biol Technol 24: 433-435.

SICK H. 1997. Ornitologia Brasileira - Edição revista e ampliada por J.F. Pacheco. Ed. Nova Fronteira, Rio de Janeiro.

SON K, KIM YK, WOO C, WANG S, KIM Y, OEM J, JHEONG W \& JEONG J. 2018 Minimizing an outbreak of avian botulism (Clostridium botulinum type C) in Incheon, South Korea. J Vet Med Sci 80(3): 553-556.

SOUZA AM, MARQUES DF, DÖBEREINER J \& DUTRA IS. 2006. Esporos e toxinas de Clostridium botulinum dos tipos C e D em cacimbas no Vale do Araguaia, Goiás. Pesqu Vet Bras 26(3): 133-138. 
SPACKMAN E, SENNE D, MYERS T, BULAGA L, GARBER L, PERDUE M, LOHMAN K, DAUM L \& SUAREZ D. 2002. Development of a real-time reverse transcriptase PCR assay for type A influenza virus and the avian $\mathrm{H} 5$ and $\mathrm{H} 7$ hemagglutinin subtypes. J Clin Microbiol 9: 3256-3260.

THIONGANE Y, LEFORBAN Y \& DOUTRE M. 1984. Le botulisme de type D au Sénégal. Un nouveau foyer d'origine hydrique responsable d’une forte mortalité. Rev Élèv Med Vet Pays Trop 2.

VIDAL D, ANZA I, TAGGART MA, PÉREZ-RAMÍREZ E, CRESPO E, HOFLE U \& MATEO R. 2013. Environmental Factors Influencing the Prevalence of a Clostridium botulinum Type C/D Mosaic Strain in Nonpermanent Mediterranean Wetlands. Appl Environ Microbiol 79(14): 4264-4271.

WŁODARCZYK R, MINIAS AP, KUKIER E, GRENDA T, ŚMIETANKA K \& JANISZEWSKI T. 2014. The First Case of a Major Avian Type C Botulism Outbreak in Poland. Am Assoc Avian Pathol 58: 488-490.

WOBESER G. 1997. Avian botulism - another perspective. Avian Wildl Dis Assoc 33: 181-186.

WOUDSTRA C, SKARIN H, ANNIBALLI F, FENICIA L, BANO L, DRIGO I, KOENE M, BÄYON-AUBOYER M, BUFFEREAU J, DE MEDICI D \& FACH P. 2012. Neurotoxin gene profiling of Clostridium botulinum types $C$ and $D$ native to different countries within Europe. Appl Env Microbiol 78: 3120-3127.

YULE AM, BARKER IK, AUSTIN JW \& MOCCIA RD. 2006. Peixes dos grandes lagos: implicações para a botulismo aviária. J Wildl Dis 3: 479-493.

ZEPPELINI CG, ALMEIDA AMP \& CORDEIRO-ESTRELA P. 2016. Zoonoses As Ecological Entities: A Case Review of Plague. PLoS Negl Trop Dis Vol. 10.

\section{How to cite}

LIMA PC, DUTRA IS, ARAÚJO FAA, LUSTOSA R, CAIO G. ZEPPELINI CG \& FRANKE CR. 2020. First record of mass wild waterfowl mortality due to Clostridium botulinum in Brazilian semiarid. An Acad Bras Cienc 92: e20180370. DOI. 10.1590/0001-3765202020180370.

Manuscript received on April 25, 2018; accepted

for publication on February 11, 2019

\section{PEDRO C. LIMA ${ }^{1}$}

https://orcid.org/0000-0002-0810-5208

\section{IVERALDO S. DUTRA ${ }^{2}$}

https://orcid.org/0000-0003-0566-7595

FRANCISCO A.A. ARAÚJO 3

https://orcid.org/ 0000-0003-4549-2726

\section{RICARDO LUSTOSA ${ }^{1}$}

https://orcid.org/0000-0001-5033-690X

\section{CAIO G. ZEPPELINI}

https://orcid.org/0000-0002-0490-4395

\section{CARLOS R. FRANKE}

https://orcid.org/0000-0001-5253-8150

${ }^{1}$ Laboratório de Infectologia Veterinária, Universidade Federal da Bahia, Rua Barão do Jeremoabo, s/n, 40170-155 Salvador, BA, Brazil

${ }^{2}$ Escola de Medicina Veterinária, Universidade Estadual Paulista, Rua Clóvis Pestana, 793, Dona Amélia, 16050-680 Araçatuba, SP, Brazil

${ }^{3}$ Faculdades Integradas da União Educacional do Planalto Central, SIGA Área Especial para Indústria Lote 2/3, Sce St. Leste Industrial, Gama, 72445-020 Brasillia, DF, Brazil

${ }^{4}$ Programa de Pós-Graduação em Ecologia: Teoria, Aplicação e Valores (PPGETAV), Universidade Federal da Bahia, Rua Barão do Jeremoabo, s/n, 40170-155 Salvador, BA, Brazil

Correspondence to: Carlos R. Franke

E-mail:frankeufba@gmail.com

\section{Author contributions}

$\mathrm{PCL}, \mathrm{RL}, \mathrm{ISD}$ were responsible for conducting the fieldwork and taxonomical identifications, CRF, CGZ and FAAA performed the lab assays. All authors contributed equally for the writing of the original manuscript in portuguese. CGZ was responsible for the article translation and editorial submission.

\section{(cc) BY}

